\title{
Summertime herbivory of coastal mesozooplankton and metazoan microplankton in the northern Baltic
}

\author{
Anna Uitto \\ Tvärminne Zoological Station, University of Helsinki, FIN-10900 Hanko, Finland
}

\begin{abstract}
Size-specific grazing by the coastal zooplankton community in the northern Baltic was studied during the summer. Experiments on grazing by mesozooplankton and metazoan microplankton, fractionated by filtration through 140 and $40 \mu \mathrm{m}$ mesh, were carried out in the laboratory with two ${ }^{14} \mathrm{C}$-labelled algae cultures, Brachiomonas submarina (size 10 to $15 \mu \mathrm{m}$ ) and Pavlova lutheri (size 4 to

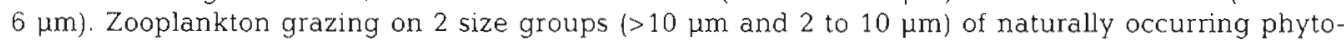
plankton was also estimated. Mesozooplankton was composed of copepods Acartia spp. and Eurytemora affinis, the cladoceran Bosmina longispina maritima, rotifers Synchaeta spp. and meroplankton; metazoan microplankton consisted mostly of copepod nauplii and rotifers. Mesozooplankton had greater biomass and higher community clearance rate (CCR) when feeding on $B$. submarina than had metazoan microplankton. For mesozooplankton, the CCR on B. submarina was dependent on successional changes of total biomass of copepods and cladocerans, whereas the CCR on $P$. lutheri was variable, probably because of less efficient grazing by copepods. The CCR of metazoan microplankton on the test algae was variable and unpredictable, possibly because of the varying biomass specific clearance rates (BSCR) of rotifers and different naupliar stages of copepods. The mean CCR on P. Iutheri did not differ between mesozooplankton and metazoan microplankton, because of the higher mean BSCR of the latter. The daily grazing of mesozooplankton on naturally occurring phytoplankton was estimated to average $9 \%$ of the daily primary production when rotifers, meroplankton or copepods were predominant, but $42 \%$ when B. longispina maritima was predominant. The integrated grazing of the mesozooplankton and metazoan microzooplankton was estimated to account for 13 and $6 \%$, respectively, of primary production during summer.
\end{abstract}

KEY WORDS: Zooplankton grazing · Northern Baltic Sea $\cdot$ Tracer feeding technique

\section{INTRODUCTION}

The particle size of available food influences the grazing efficiency of many metazooplankton species, including mesozooplankton and metazoan microplankton. The optimal food size of different developmental stages of copepods is reported to increase with increasing body size of the grazer (Paffenhöfer 1971, Bergreen et al. 1988). Cladocerans graze more effectively on smaller food particles than do copepods (Peters \& Downing 1984). The food preferences of rotifers vary widely, some species being highly selective, others consuming a range of particles, from bacteria to other rotifers (Bogdan \& Gilbert 1982, Arndt et al. 1990).

Metazoan microplankton, such as copepod nauplii, have higher biomass specific grazing rates and meta- bolic rates than larger mesozooplankton (Moloney \& Field 1989, White \& Roman 1992). Body size influences the grazing efficiency of different species and ultimately the grazing impact of whole zooplankton communities (Cyr \& Pace 1993). Thus, species composition, size structure and biomass of a metazooplankton community are important factors affecting its grazing pressure on available food, where this food consists of different sized food particles. However, the size selectivity of zooplankton grazing and its ecological consequences have not been studied at the community level, but rather single zooplankton species have been used, mostly in artificial laboratory conditions (see Turner \& Tester 1989 for critique). Laboratory experiments reveal important information on species-specific grazing characteristics, but the interpretation of natural 
communities in the light of laboratory measurements is ambiguous, because many temporally and spatially changing abiotic and biotic factors influence species' grazing behaviour in nature.

In this study, the size selectivity and grazing efficiency of the coastal communities of mesozooplankton and metazoan microzooplankton was investigated during summer in the sea area off Tvärminne, on the southwest coast of Finland. The area is suitable for such studies, because species diversity is relatively low and successional changes in metazooplankton communities are clear. The rotifer Synchaeta spp. is common in early summer and its biomass occasionally increases in late summer (Kivi 1986). Calanoid copepods, especially Acartia spp. (mostly Acartia bifilosa Giesbr.) and Eurytemora affinis (Poppe), and the cladoceran Bosmina longispina maritima (P. E. Müller) often predominate in the summer (Forsskàhl \& Sundberg 1981, Vuorinen \& Ranta 1987).

In the grazing experiments, a modified vesion of Haney's (1971) method was used, but the experiments were carried out in the laboratory. Two cultures of different sized autotrophic nanoflagellates were used as tracer food particles, because naturally occurring phytoplankton of the study area is often dominated by nanoflagellates during summer (Niemi 1973, Forsskåhl \& Sundberg 1981, Huttunen \& Kuparinen 1986). The specific hypothesis tested during summer 1988 was that successional changes in the structure and biomass influence the size selectivity and grazing efficiency of mesozooplankton and metazoan microplankton communities. The potential consequences of the zooplankton grazing for primary production, and for the size structure of naturally occurring nanophytoplankton. are discussed.

\section{MATERIALS AND METHODS}

Size fractionation of the zooplankton community. Grazing measurements of zooplankton were based on the fractionation of the zooplankton community into different size fractions after the grazing experiments (cf. Mazumder et al. 1990). For these purposes, preliminary studies of the zooplankton size structure were carried out by fractionating $4 \mathrm{l}$ zooplankton samples through nylon filters with mesh sizes of 200,140 , $100,80,40$ and $20 \mu \mathrm{m}$. The efficiency of these filters was examined in a filter fractionation device, constructed with plexiglas funnels (Nalgene) installed on a tripod one above the other. The 140,100 and $40 \mu \mathrm{m}$ filters were most suitable for fractionation of the zooplankton community into 3 categories: mesozooplankton (copepods, cladocerans, rotifers and meroplankton); large metazoan microplankton (copepod nauplii, smallest rotifers and meroplankton passing the $1.40 \mu \mathrm{m}$ filter); and small metazoan microplankton (mostly copepod nauplii).

Preparation of algal cultures. Clearance and ingestion rates of zooplankton were measured using two ${ }^{14} \mathrm{C}$-labelled algal cultures: Brachiomonas submarina Bohlin (Chlorophyceae) and Pavlova lutheri (Droop) Green (Prymnesiophyceae). The diameters of these species varied from 10 to $15 \mu \mathrm{m}$ and from 4 to $6 \mu \mathrm{m}$ respectively, corresponding to mean volumes of 500 and $60 \mu \mathrm{m}^{3}$. The algal cultures were labelled with ${ }^{14} \mathrm{C}$ $\left(1 \mu \mathrm{Ci} \mathrm{NaH}{ }^{14} \mathrm{CO}_{3} \mathrm{ml}^{-1}\right)$, and incubated in a shaker for $24 \mathrm{~h}$ under a light intensity of 40 to $60 \mu \mathrm{E} \mathrm{cm}^{-2} \mathrm{~s}^{-1}$ The final mean radioactivities of the cultures were $0.89 \mu \mathrm{Ci}$ $\mu \mathrm{gC}^{-1}$ for $B$. submarina and $0.78 \mu \mathrm{Ci} \mu \mathrm{gC}^{-1}$ for $P$. lutheri. Cell concentrations of unlabelled controls of algal cultures were determined by counting at least 500 cells ( 3 replicates) on a hemocytometer. The mean final concentration of cells added was $4144 \mathrm{ml}^{-1}$ for $B$. submarina and $4109 \mathrm{ml}^{-1}$ for $P$. lutheri, with carbon contents of $0.228 \mu \mathrm{g} \mathrm{C} \mathrm{ml} l^{-1}$ and $0.027 \mu \mathrm{gC} \mathrm{ml}^{-1}$ respectively. The carbon content for the test algal cultures was calculated from their specific biovolumes, assuming a carbon percentage of $11 \%$ of the cell plasma volume (Edler 1979).

Grazing experiments. A composite water sample of $35 \mathrm{I}$ was taken from a depth of $5 \mathrm{~m}$ and transferred to the laboratory for the grazing experiments. First, a phytoplankton subsample of $500 \mathrm{ml}$ was taken and preserved with acid Lugol's solution. To determine the composition of the fractionated zooplankton community in each grazing experiment, 2 or 3 water subsamples of 4 l were taken from the composite sample and fractionated through a series of filters of 140,100 and $40 \mu \mathrm{m}$ before the grazing experiments. These filters were placed into separate $20 \mathrm{ml}$ bottles that were them filled with filtered sea water and preserved with formalin. For enumeration of organisms, the filters were placed carefully on the inside wall of separate sedimentation chambers (volume $100 \mathrm{ml}$, length $10 \mathrm{~cm}$ ), into which the preserved zooplankton was rinsed from the bottles and filters with filtered sea water. Examination with a microscope showed that the rinsing was sufficient to remove the animals from the nylon filters. The zooplankton and phytoplankton samples were counted using the Utermöhl technique (1958). The biovolumes of the species were converted to organic carbon assuming carbon percentages of 5.2 for metazooplankton (Mullin 1969) and 11 for phytoplankton and ciliates (Edler 1.979).

To avoid some of the potential errors associated with metazooplankton grazing experiments (Gulati 1985), the experiments were conducted with the unconcentrated samples of naturally occurring zooplankton. These were fractionated into mesozooplankton and metazoan microplankton immediately after the experi- 
ments, without preservation or sorting of zooplankton individuals. For the grazing experiments with both test algae, 5 zooplankton subsamples of 21 were taken from the same composite sample from which samples for zooplankton biomass determinations were taken. The water in the experimental units was stabilised for several hours at the in situ temperature before carrying out the experiments. At the beginning of the experiments, 0.5 to $4 \mathrm{ml}$ of the radiolabelled culture of Brachiomonas submarina and Pavlova lutheri were added to separate experimental units of 2 l (4 replicates for each test alga) to give a final concentration of about 4000 cells $\mathrm{ml}^{-1}$. The concentrations of test algae were fixed at the same numerical level, because metazooplankton probably experience phytoplankton food mainly in terms of cell numbers, rather than particle biomass (cf. Turner \& Tester 1989). In the experiments, the concentrations of test algae and natural phytoplankton were at the lower end of the critical food concentration for metazooplankton reported by Peters (1984 and references therein).

Incubation times for the experimental units were approximately $0,10,25$ and $45 \mathrm{~min}$ for the experiments with both test algae. To prevent the egestion of tracer food during filtration, the zooplankton community was anaesthetised by adding soda water $(1 / 10)$ to the experimental units, after which the water was passed through a series of filters $(140,100$ and $40 \mu \mathrm{m})$. The filters were put directly into $20 \mathrm{ml}$ scintillation vials for radioactivity measurements. Inorganic ${ }^{14} \mathrm{C}$ was evaporated for 24 h after adding $100 \mu 1 \mathrm{~N} \mathrm{HCl}$ (Niemi et al. 1983). Seven millilitres of PCS liquid scintillation cocktail (Amersham, UK) were added to the bottles, and because of the high dissolving impact of the PCS's xylene, no other solubilizer was needed. Radioactivity measurements were performed with a Wallac 1219 Rack Beta liquid scintillation counter (LKB-Wallac Co., Turku, Finland). The experiments were run 6 times during summer between 16:00 and 19:00 h. Since the zooplankton fractions on 100 and $40 \mu \mathrm{m}$ filters appeared to be very similar, both containing mostly copepod nauplii and Synchaeta spp., their biomass as well as the ${ }^{14} \mathrm{C}$ results of grazing experiments were combined together to form only one size fraction of metazoan microplankton, to be compared with the $>140 \mu \mathrm{m}$ mesozooplankton. In later examinations, only these 2 fractions are considered.

Because the added algal cultures included a small amount of inorganic ${ }^{14} \mathrm{C}$, the additional intake of ${ }^{14} \mathrm{C}$ from sources other than test algae (incorporation of inorganic ${ }^{14} \mathrm{C}$ and grazing on natural phytoplankton labelled during the experiments) was checked in the 2 zooplankton size fractions on one occasion in August.

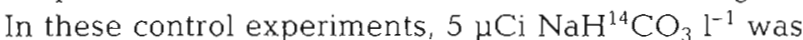
used, but without the addition of algal cultures. The
Table 1 Regression analysis of the biomass specific intake rate $\left(\mathrm{dpm} \mu \mathrm{gC}^{-1} \mathrm{~min}^{-1}\right)$ of the free tracer $\left(5 \mu \mathrm{Ci} \mathrm{NaH}{ }^{14} \mathrm{CO}_{3} \mathrm{l}^{-1}\right)$ in 2 zooplankton size fractions. $t$ : time in minutes

\begin{tabular}{|lccc|}
\hline Size fraction & $\mathrm{r}^{2}$ & $\mathrm{p}$ & $\mathrm{n}$ \\
\hline$>140 \mu \mathrm{m}$ & & & \\
$\quad 0.7052-0.0101 t+0.0003 t^{2}$ & $67 \%$ & $<0.05$ & 8 \\
$40 \mathrm{t} 0140 \mu \mathrm{m}$ & & & \\
$2.5127-0.0441 t+0.0018 t^{2}$ & $93 \%$ & $<0.001$ & 8 \\
\hline
\end{tabular}

amount of inorganic ${ }^{14} \mathrm{C}$ in the experimental units with Brachiomonas submarina was between 22 and $36 \%$ of the level used in the control experiment, and between 4 and $35 \%$ in the units with Pavlova lutheri. The biomass specific intake rate of ${ }^{14} \mathrm{C}\left(\mathrm{dpm} \mu \mathrm{g} \mathrm{C}^{-1} \mathrm{~min}^{-1}\right)$ was calculated by regression analysis including linear and quadratic coefficients, because the radioactivity increase of zooplankton is a parabolic function of time (Daro 1978) (Table 1). In the experiments with B. submarina, the intake of additional ${ }^{17} \mathrm{C}$ was at most $7 \%$ of the total label intake (intake of test alga + labelled phytoplankton + incorporation of inorganic ${ }^{14} \mathrm{C}$ ) in the 40 to $140 \mu m$ zooplankton size fraction. The level usually remained below $1 \%$ for all size fractions in experiments with both test algae, due to the short experimentation time (10 to $50 \mathrm{~min}$ ). The community clearance rate (CCR; $\mathrm{ml} \mathrm{l}^{-1} \mathrm{~h}^{-1}$ ) was then calculated with the equation:

$$
\frac{d p m_{t A}-d p m_{t 0}-d p m_{t B}}{d p m_{x}} \times \frac{1}{V} \times \frac{1}{t} \times 60
$$

where $\mathrm{dpm}_{\mathrm{lA}}$ is total activity of the filtered biomass at time $t_{i} \mathrm{dpm}_{10}$ is activity of the filtered biomass at time $t_{0} ; \mathrm{dpm}_{t \mathrm{~B}}$ is activity of the filtered biomass due to intake of additional ${ }^{14} \mathrm{C}_{;} \mathrm{dpm}_{\mathrm{x}}$ is activity of the tracer in $\mathrm{ml} ; \mathrm{V}$ is volume of the bottles ( $2 \mathrm{l}$ ); and $t$ is incubation time in minutes

The CCR of both zooplankton size fractions was calculated as a mean of the clearance rate values $(n=3)$, corresponding to the points of the linear accumulation of ${ }^{14} \mathrm{C}$ of both tracer foods at times $t_{1}$ to $t_{3}$. To determine an overall grazing efficiency, the biomass specific clearance rate (BSCR; $m l \mu \mathrm{gC}^{-1} \mathrm{~h}^{-1}$ ) was calculated by dividing community clearance rate by community biomass.

The grazing of zooplankton on naturally occurring phytoplankton was estimated using the measured CCR on the test algae. Data from the natural phytoplankton samples were divided into 2 groups: cells larger than $10 \mu \mathrm{m}$, and cells from 2 to $10 \mu \mathrm{m}$, corresponding to the cell sizes of $>500 \mathrm{\mu m}^{3}$ and $60 \mathrm{\mu m}^{3}$, respectively, of the ${ }^{14} \mathrm{C}$-labelled algae, Brachiomonas submarina and Pavlova lutheri. Grazing on the larger 
phytoplankton category was estimated using the CCRs of meso- and microzooplankton when feeding on $B$. submarina, and grazing on the smaller phytoplankton using the CCRs on P. lutheri. The biomass of Aphanizomenon flos-aquae (L.) Ralfs was not included in the larger phytoplankton group, because metazooplankton do not feed effectively on large filamentous bluegreen algae (cf. Webster \& Peters 1978). All other species were assumed to be palatable to zooplankton.

\section{RESULTS}

\section{Zooplankton succession}

In the study area, the mean biomass of mesozooplankton exceeded that of metazoan microplankton in summer (2-sample t-test for whole log-transformed data set; $p=0.000, n=24$ ) (Fig. 1). An increase in rotifer and meroplankton (mostly lamellibranch larvae) biomass produced a mesozooplankton biomass maximum in June. One-third of rotifer biomass was accounted for by Synchaeta monopus Plate, the rest being formed by $S$. baltica Ehrenberg. In the middle of July, this community was replaced by calanoid copepods Eurytemora affinis and Acartia spp. and the biomass decreased. Later on, the cladoceran Bosmina longispina maritima was predominant, along with copepodite and adult stages of the copepod Acartia spp.

In June, the biomass of metazoan microplankton was composed of Synchaeta spp. and meroplankton. Acartia spp. and Eurytemora affinis nauplii were equal in biomass in the first 3 experiments, but later on, $80 \%$ of naupliar biomass was composed of Acartia spp. On average, $7 \%$ of naupliar biomass was composed of Temora longicornis and $<1 \%$ of Cyclops spp. Peritrich and tintinnid ciliates were found on the $40 \mu \mathrm{m}$ filter, but their biomass was quite low. The coefficient of variation (CV, \%) between duplicate zooplankton biomass subsamples averaged $9 \%$ for both mesozooplankton and metazoan microplankton.

\section{Grazing experiments}

The hourly CCR of mesozooplankton varied between 1 and $6 \mathrm{ml} \mathrm{l}^{-1}$, and BSCR between 0.01 and $0.19 \mathrm{ml}$ $\mu \mathrm{gC}^{-1}$. For metazoan microplankton, the corresponding

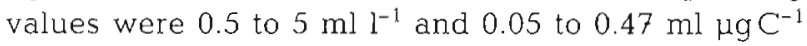
(Fig. 2A, B). The CCR of mesozooplankton feeding on

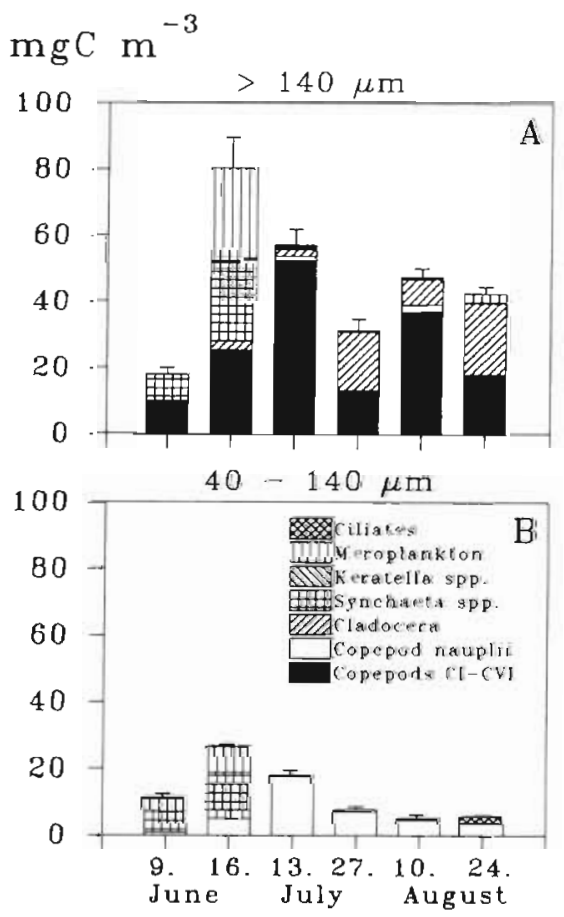

Fig. 1. Zooplankton biomass $\left(\mathrm{mg} \mathrm{C} \mathrm{m}^{-3}\right.$ ) at $5 \mathrm{~m}$ depth in the sea area off Tvärminne in 1988. (A) Mesozooplankton of the $>140 \mu \mathrm{m}$ size fraction (bar shading as in B); (B) metazoan microplankton and ciliates of the 40 to $140 \mu \mathrm{m}$ size fraction. Error bars indicate the variation between duplicate samples
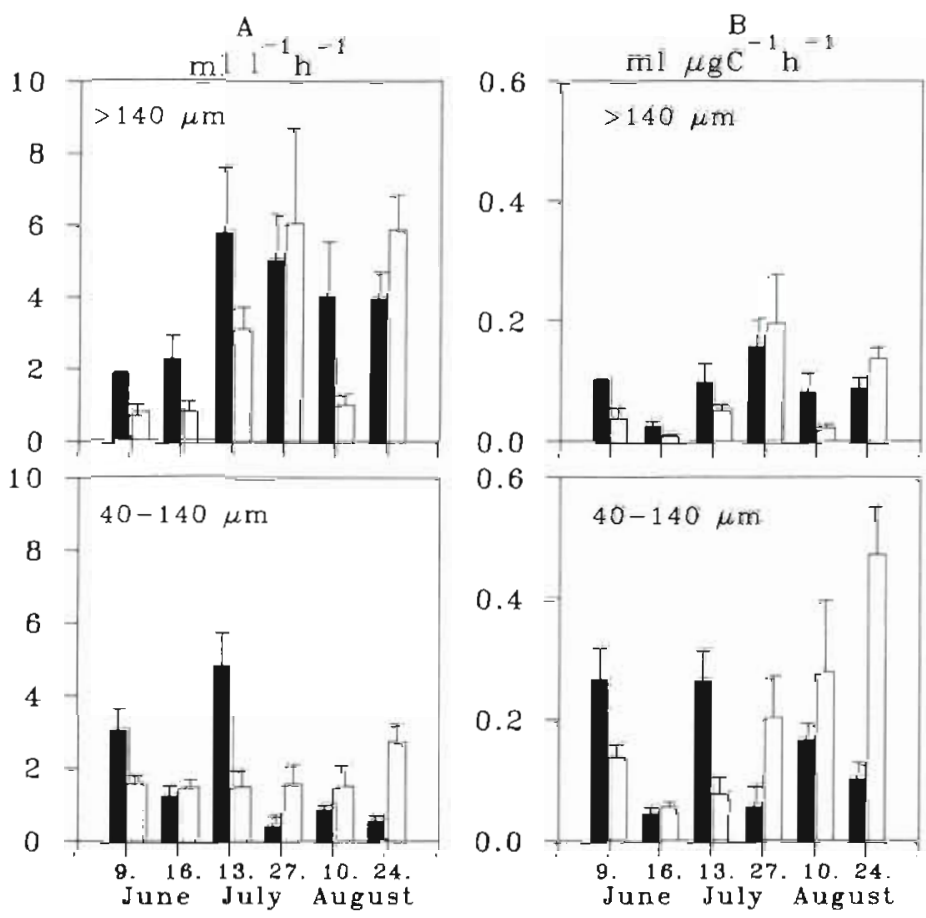

Fig. 2. (A) Community clearance rates (CCR, $\mathrm{ml} \mathrm{l}^{-1} \mathrm{~h}^{-1}$ ), and (B) biomass specific clearance rates (BSCR, $\mathrm{ml} \mu \mathrm{g} \mathrm{C}^{-1} \mathrm{~h}^{-1}$ ) on Brachiomonas submarina (black bars) and Pavlova lutheri (white bars) of the $>140 \mu \mathrm{m}$ and 40 to $140 \mu \mathrm{m}$ zooplankton size fractions. Error bars indicate 1 standard deviation of the 3 replicated experiments 
both test algae increased after June, following the biomass growth of mesozooplankton, but the CCR and BSCR on Pavlova lutheri varied more than on Brachiomonas submarina. For metazoan microplankton, the CCR varied more when feeding on $B$. submarina than on $P$. lutheri, but the highest temporal variations appeared in the BSCR on $P$. Iutheri. The CV between 3 replicates averaged 22 and $25 \%$ for grazing experiments with $B$. submarina and 38 and $26 \%$ for experiments with $P$. lutheri for mesozooplankton and metazoan microplankton, respectively. The mean CCR on B. submarina was higher in mesozooplankton than in metazoan microplankton ( $p=0.0004)$,

but no difference was found in the BSCR ( $p=0.13$ ) when the whole log-transformed data set ( $n=36$ ) was tested with a 2 -sample $t$-test. In contrast, there was no difference in the mean CCR on $P$. lutheri between mesozooplankton and metazoan microplankton $(\mathrm{p}=$ 0.49); this was because the mean BSCR of metazoan microplankton was much higher than that of mesozooplankton ( $p=0.0005)$.

To study the grazing efficiency of mesozooplankton communities dominated by different species, the data sets of 6 experiments were pooled to form 3 entities. The first and second experiments were combined to reflect the grazing of a Synchaeta-meroplankton-Acartia assemblage (SMA); the third and fifth experiments, a copepod assemblage; and the fourth and sixth experiments, a cladoceran assemblage. The SMA and copepod assemblages both had significantly higher BSCR when feeding on Brachiomonas submarina than on Pavlova lutheri (Wilcoxon signed rank test; $p=0.04, n=$ 12), but no such difference was found for the cladoceran assemblage $(p=0.4, n=12)$. It was not reasonable to test the BSCR of 2 metazoan microplankton assemblages (Synchaeta-meroplankton and copepod nauplii), because there were high variations in BSCR on the test algae between zooplankton communities with similar community structures.

In the experiments with both test algae, a positive correlation between temperature and CCR was found for mesozooplankton (Table 2). The biomass of Synchaeta spp. correlated negatively with the mesozooplankton CCR on Brachiomonas submarina, but the total copepod and cladoceran biomass showed a positive correlation. The biomass of Bosmina longispina maritima correlated positively with the CCR on Pavlova lutheri. For metazoan microzooplankton, BSCR on $P$. lutheri correlated negatively with meroplankton and total metazooplankton biomass. A posi- tive correlation was also found between ciliate biomass and BSCR of the 40 to $140 \mu \mathrm{m}$ size fraction.

\section{Extrapolation of the grazing measurements to the natural pelagic ecosystem of the study area}

In the study area, primary production varied between 8 and $52 \mathrm{mg} \mathrm{C} \mathrm{m}{ }^{-3} \mathrm{~d}^{-1}$ at a depth of $5 \mathrm{~m}$ during the summer (R. Lignell pers. comm.) (Fig. 3A). Nanoflagellates dominated the biomass of autotrophic phytoplankton. Phytoplankton $>10 \mu \mathrm{m}$ consisted mostly of Eutreptiella gymnastica Throndsen, Pseudopedinella elastica Skuja, Katodinium rotundatum (Lohmann) Fott, Chaetoceros wighamii Brightwell and Skeletonema costatum (Greville) Cleve. Phytoplankton 2 to $10 \mu \mathrm{m}$ included Chrysochromulina spp., Cryptomonas spp., Pyramimonas spp. and Pedinella tricostata Rouchijajnen (Fig. 3B). The biomass of the filamentous blue-green alga Aphanizomenon flosaquae increased at the end of August.

The estimated daily grazing on naturally occurring phytoplankton varied between 1 and $6 \mathrm{mg} \mathrm{C} \mathrm{m}^{-3} \mathrm{~d}^{-1}$ for mesozooplankton and between 1 and $4 \mathrm{mg} \mathrm{C} \mathrm{m}{ }^{-3}$ $\mathrm{d}^{-1}$ for metazoan microzooplankton (Fig. 3C). The daily grazing of mesozooplankton exceeded that of metazoan microplankton, except in early June. Mesozooplankton were estimated to graze 4 to $14 \%$ of phytoplankton biomass daily, and metazoan microplankton, 2 to $7 \%$. The daily biomass specific grazing efficiency on naturally occurring phytoplankton (\% of zooplankton C) varied between 3 and $14 \%$ for mesozooplankton and 5 and $35 \%$ for metazoan microplankton (Table 3). The estimated daily grazing of mesozooplankton varied between 7 and $54 \%$ of the daily primary production, and of metazoan microplankton between 2 and $15 \%$ Integrated over the whole study period, the cor- 

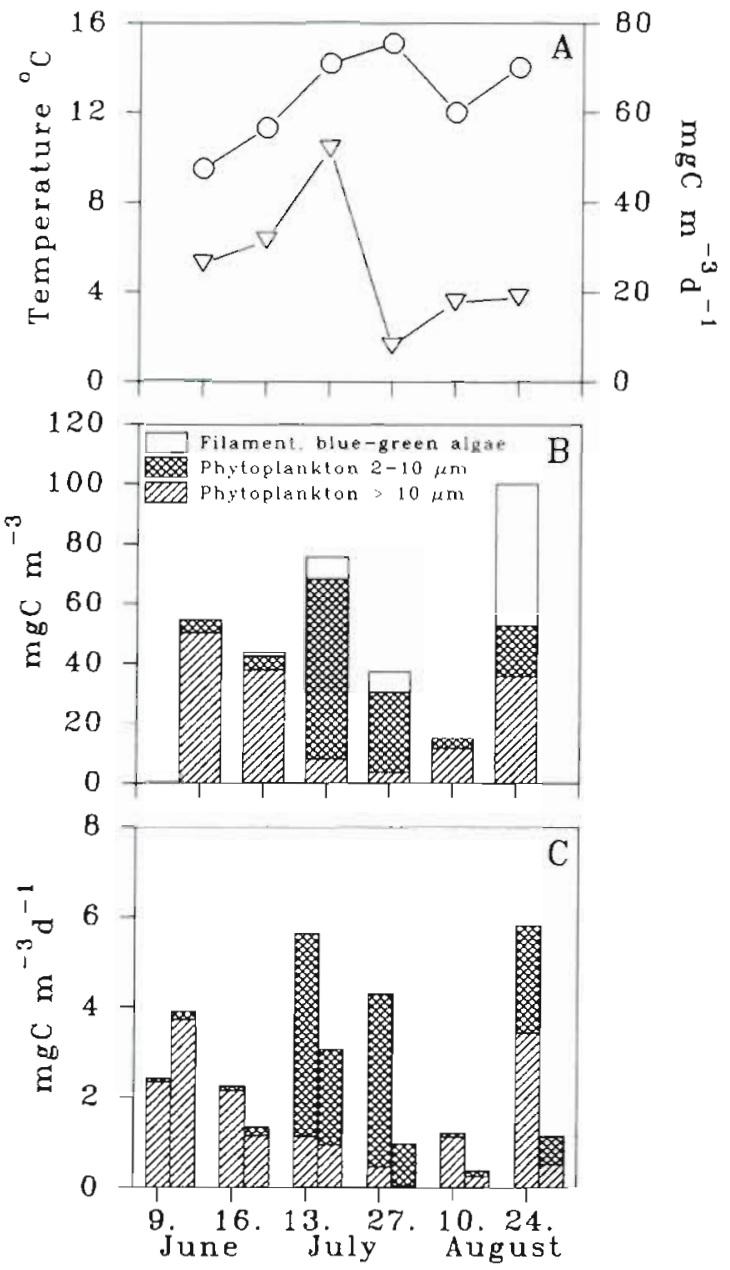

Fig. 3. Summary of environmental parameters and grazing estimates at the study area. (A) Temperature $\left({ }^{\circ} \mathrm{C}\right.$, circles) and primary production ( $\mathrm{mg} \mathrm{C} \mathrm{m}^{-3} \mathrm{~d}^{-1}$, triangles) (R. Lignell unpubl.); (B) biomass of phytoplankton ( $\mathrm{ng} \mathrm{C} \mathrm{m}^{-3}$ ); (C) daily

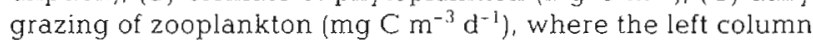
denotes mesozooplankton, and the right column, metazoan microplankton (bar shading in B)

responding percentages are $13 \%$ for mesozooplankton and $6 \%$ for metazoan microplankton. In these estimations, zooplankton were assumed to feed continuously throughout the $24 \mathrm{~h}$ cycle, without significant vertical migration, as has been found to be the case in the southern Baltic (Nicolajsen et al. 1983).

\section{DISCUSSION}

\section{Factors affecting grazing efficiency during summer}

\section{Mesozooplankton}

Changes in community structure and biomass influenced the grazing efficiency of mesozooplankton dur- ing summer. The CCR on Brachiomonas submarina was dependent, in an almost linear manner, on total biomass of copepods and cladocerans, but the CCR on Pavlova Jutheri was more variable because of the lower grazing efficiency of copepods on $P$. lutheri. This agrees with other studies where adults and copepodite stages of copepods were found to prefer particles $>10 \mu \mathrm{m}$ as food both in situ (Dam \& Peterson 1991, Bautista \& Harris 1992) and in laboratory experiments (Bergreen et al. 1988). The grazing of communities dominated by Bosmina longispina maritima was nonselective, but they seemed to graze more effectively on $P$. Iutheri than did other mesozooplankton. $B$. longispina maritima has been found to graze effectively on particles ranging from $<5$ to $25 \mu \mathrm{m}$ (Hessen et al. 1986), especially on small nanoflagellates, which are not available to larger mesozooplankton (DeMott \& Kerfoot 1982).

The BSCR of mesozooplankton decreased in June, although the community structure did not change remarkably, and biomass increased. Assuming a rough gross growth efficiency of $30 \%$ (cf. Riemann et al. 1990) for mesozooplankton biomass, the integrated grazing on naturally occurring phytoplankton could fulfil, at most. $8 \%$ of the community's carbon demand. If meroplankton is excluded from this calculation, the percentage is still as low as $13 \%$. Synchaeta spp. and Acartia spp. (Lindholm 1981, Tiselius 1989, Arndt et al. 1990) are known to feed on ciliates in the Baltic. Thus, feeding on protozooplankton may have satisfied a considerable proportion of the nutritive demand of mesozooplankton in early June. The grazing may also have been constrained in the crowded zooplankton community with the maximum biomass in the middle of June.

Mesozooplankton communities dominated by Bosmina longispina maritima had the highest BSCR on Pavlova lutheri in late summer. This cladoceran becomes abundant when temperatures rise during summer in the northern Baltic (Kankaala 1983), as was the case in this study. The increase in B. longispina maritima biomass was also associated with the decline of the smaller phytoplankton of size 2 to $10 \mu \mathrm{m}$, which corresponds to the size of $P$. lutheri and other nanoflagellates found to be palatable for $B$. longispina maritima (DeMott \& Kerfoot 1982, Hessen et al. 1986). The results of this study fit well with the findings of Kankaala \& Wulff (1981) and Kankaala (1983), who assumed food conditions and temperature to be the main limiting factors for $B$. longispina maritima during the summer in the northern Baltic Sea. With its higher grazing efficiency on algae $<10 \mu \mathrm{m}, B$. longispina maritima may be superior to copepods in its use of late summer phytoplankton, which is dominated by small flagellates in the study area. 
Table 3. Estimated daily biomass specific grazing efficiency (\% of zooplankton C) of mesozooplankton and metazoan microplankton in the sea area of Tvärminne during summer 1988, compared with other in situ measurements with naturally occurring phytoplankton. Chl a concentrations were converted to C assuming a carbon:chl a ratio of 40 . F: adult females

\begin{tabular}{|c|c|c|c|c|c|}
\hline \multicolumn{2}{|c|}{$\begin{array}{c}\text { Daily grazıng (\% of } \\
\text { zooplankton } \mathrm{C})\end{array}$} & Sea area & \multirow[t]{2}{*}{$\begin{array}{l}\text { Temp. } \\
\left({ }^{\circ} \mathrm{C}\right)\end{array}$} & \multirow[t]{2}{*}{$\begin{array}{l}\text { Food conc. } \\
\left(\mu \mathrm{gCl}^{-1}\right)\end{array}$} & \multirow[t]{2}{*}{ Source } \\
\hline Mesozooplankton & & & & & \\
\hline SMA assemblage & $3-13$ & Coastal N Baltic Sea & $10-11$ & $43-55$ & This study, Expts 1 \& 2 \\
\hline Copepod assemblage & $3-10$ & Coastal N Baltic Sea & $12-14$ & $15-68$ & This study, Expts $3 \& 5$ \\
\hline Bosmina longispina maritima assemblage & $13-14$ & Coastal N Baltic Sea & $14-15$ & $30-53$ & This study, Expts $4 \& 6$ \\
\hline Centrophages hamatus $\mathrm{F}$ & $3-12$ & Oresund & $1-12$ & $8-1140$ & Nicolajsen et al. $\{1983\}$ \\
\hline Pseudocalanus sp. F & $0.2-14$ & Øresund & $1-12$ & $8-1140$ & Nicolajsen et al. (1983) \\
\hline Temora longicornis $\mathrm{F}$ & 18 & Kattegat-Skagerrak & 2 & 192 & Kiorboe et al. (1985) \\
\hline Acartia spp. F & 25 & Kattegat-Skagerrak & 2 & 76 & Kiorboe et al. (1985) \\
\hline Acartia spp. CI-CVI & $44-92$ & E North Sea estuary & & $300-420$ & Tackx et al $\{1990\}$ \\
\hline Eurytemora spp. Cl-CVI & $137-645$ & ENorth Sea estuary & & $800-2200$ & Gulati \& Doornekamp (1991) \\
\hline Acartia tonsa Cl-CVI & $58-183$ & Chesapeake Bay & $15-26$ & $180-1620$ & White \& Roman (1992) \\
\hline A. tonsa F & $74-85$ & Narragansett Bay & 13 & 200 & Durbin et al. (1990) \\
\hline Eurytemora spp. Cl-CVI & 8 & Chesapeake Bay & $4-15$ & $180-1620$ & White \& Roman (1992) \\
\hline Cladoceran & 42 & Chesapeake Bay & $15-17$ & $180-1620$ & White \& Roman (1992) \\
\hline Rotifer & 37 & Chesapeake Bay & $4-26$ & $180-1620$ & White \& Roman (1992) \\
\hline \multicolumn{6}{|l|}{ Metazoan microplankton } \\
\hline Synchaeta-meroplankton assemblage & $5-35$ & Coastal N Baltic Sea & $10-11$ & $43-55$ & This study, Expts $1 \& 2$ \\
\hline Copepod naupli assemblage & $8-29$ & Coastal N Baltic Sea & $12-15$ & $15-68$ & This study, Expts 3 to 6 \\
\hline Acartia spp nauplii & $28-52$ & E North Sea estuary & & $300-420$ & Tackx et al. $(1990)$ \\
\hline Acartia spp nauplii & $79-280$ & Chesapeake Bay & $15-26$ & $180-1620$ & White \& Roman (1992) \\
\hline
\end{tabular}

\section{Metazoan microplankton}

The grazing efficiency of metazoan microplankton was variable and unpredictable, even between communities with almost the same community structure. Metazoan microplankton was composed of meroplankton and Synchaeta spp. in June, which grazing efficiency probably decreased for the same reasons as in mesozooplankton. The varying grazing efficiencies of copepod nauplii may have caused the variability in July and August. In this study, the naupliar biomass of Acartia spp and Eurytemora affinis was equal in the middle of July, when the BSCR of metazoan microplankton was higher when feeding on Brachiomonas submarina than on Pavlova lutheri. The preferences seemed to be opposite when the biomass of Acartia spp. nauplii exceeded approximately 5 times the biomass of $E$. affinis nauplii later in the summer. In the northern Baltic, Acartia bifilosa and E. affinis occur at the same time during summer, which suggests that they do not compete for food resources (Viitasalo 1994). Differences in naupliar feeding may be one reason the species are able to coexist.

The irregular feeding and variation in the food size selectivity of different stages of copepod nauplii may have also caused variability in the BSCR and CCR. The naupliar stage NI of many species has been found to be non-feeding (Huntley \& Brooks 1982, Uye et al. 1990, Zánkai 1991), and the feeding of some crustaceans can cease or be depressed before moulting to the next stage (Lasker 1966, Paffenhöfer 1971). Bergreen et al.
(1988) found the optimum food sizes for the naupliar stages NII to NIV of Acartia tonsa to be $7 \mu \mathrm{m}$, with subsequent stages preferring particles of $14 \mu \mathrm{m}$ in size, corresponding to the sizes of Pavlova lutheri and Brachiomonas submarina respectively in this study. The BSCR of metazoan microplankton dominated by Acartia spp. nauplii increased when feeding on $P$. lutheri during July and August, and this may have been caused by varying naupliar feeding efficiency and food size selectivity, if successive communities were dominated by different naupliar stages. Ciliates occurring on the $40 \mu \mathrm{m}$ filter could possibly also have increased the BSCR on P. Iutheri in the last experiment.

\section{Mesozooplankton versus metazoan microplankton}

Because of its larger mean biomass, mesozooplankton mean CCR exceeded 2-fold that of the metazoan microplankton, at least when Brachiomonas submarina was used as food. However, the mean BSCR of microzooplankton on Pavlova lutheri was approximately 3 times higher than that of mesozooplankton, which reduces the differences in mean CCR between mesozooplankton and metazoan microplankton on P. lutheri to non-significant levels. Regarding separate experiments conducted during summer, the CCR on both test alga seemed to be even higher in metazoan microplankton than in mesozooplankton. Based on allometric predictions calculated for freshwater crustacean zooplankton in 90 lakes, Cyr \& Pace (1993) suggested 
that, of 2 communities with equal community biomass, the one dominated by smaller zooplankton should graze more than the other. In the northern Baltic the biomass of metazoan microplankton is usually smaller than that of mesozooplankton in summer (cf. Vuorinen \& Ranta 1987). However, having higher BSCR, metazoan microplankton may occasionally graze more on nanoflagellates $<10 \mu \mathrm{m}$ than does mesozooplankton.

\section{Effects of temperature and food concentration}

Temperature increase is known to have a positive effect on mesozooplankton grazing, especially on that of copepods (Dam \& Peterson 1988, Durbin \& Durbin 1992). In this study, in situ temperatures used in grazing experiments (Fig. 3A) correlated significantly with the CCRs of the mesozooplankton (Table 2). However, this was not found for BSCR, which could be considered the most valid indicator of the effects of changing temperature. Thus, the possible direct effect of temperature on CCR cannot be distinguished from the effects of the changes in community structure and biomass, which may in turn have been influenced indirectly by the effects of temperature, food quality and quantity, and inter-and intraspecific interactions. The estimated daily biomass specific grazing efficiencies (\% of community $C$ ) of mesozooplankton and metazoan microplankton dominated by different species were similar to those measured at approximately the same temperatures and food concentrations of naturally occurring phytoplankton (Table 3). Higher temperatures and especially food concentrations could produce higher biomass specific grazing efficiencies for mesozoan species in situ, an effect which has been shown for copepods in many laboratory studies (cf. Durbin \& Durbin 1992 and references therein).

\section{Zooplankton grazing and primary production}

The estimated ratio between daily mesozooplankton grazing and daily primary production varied between 7 and $11 \%$ for communities dominated by copepods or Synchaeta spp. and meroplankton. The ratios are within the range of those measured for copepods or for copepod dominated communities by Tiselius (1988) in the southern Baltic ( 5 to $48 \%$ ), Morales et al. (1993) in the northeast Atlantic (1 to $22 \%$ ), White \& Roman (1992) in Chesapeake Bay (12 to $103 \%$ ), Tackx et al. (1990) in an estuary of the southwestern Netherlands (11 to $18 \%$ ), and Conover \& Mayzaud (1984) in an inlet in Nova Scotia, Canada (10 to $30 \%)$. In this study, the highest grazing percentages of $54 \%$ and $31 \%$ coincided with the presence of communities dominated by Bosmina longispina maritima after the decline in primary production associated with diminishing phytoplankton biomass at the end of July. High grazing efficiencies are reported by Vadstein et al. (1989) and Markager et al. (1994) for freshwater cladoceran communities.

The ratio between daily grazing by metazoan microplankton and daily primary production varied between 2 and $15 \%$ during summer. This range is comparable with those calculated for microzooplankton (tintinnids, oligotrich ciliates and rotifers) by Riemann et al. (1990) in the southern Baltic ( 7 to $11 \%$ ) and for copepod nauplii by White \& Roman (1992) in Chesapeake Bay (1 to $23 \%$ ). The measured ratio between zooplankton grazing and primary production may vary widely due to differences in methods used, season, time of day, depth of water and study area.

The integrated grazing by metazooplankton was estimated to account for $19 \%$ of primary production in summer, which exceeds the percentage found by Lignell et al. (1993) for the preceding spring in the same area. They estimated that the proportion of primary production grazed by metazooplankton was only $2 \%$ during the growing phase of the bloom and $12 \%$ during the declining phase. The small-sized Synchaeta littoralis accounted for most of the grazing during the former phase and, together with the copepod Acartia spp, during the latter. In this study, the grazing by metazooplankton dominated by Synchaeta spp., meroplankton and copepods accounted for $15 \%$ of primary production in the first half of the experiment and $24 \%$ during the second half, but the efficiency of the grazing varied widely because of the relative predominance of Bosmina longispina maritima or copepods.

\section{Reliability of the grazing estimates}

In this study, the grazing experiments conducted with the cultured nanoflagellates Brachiomonas submarina and Pavlova lutheri are likely to provide a reasonable estimate for the zooplankton grazing on autotrophic nanoplankton, which is dominated by nanoflagellates at a depth of $5 \mathrm{~m}$ in the study area during summer. However, by using only 2 test algae, these estimations will be quite crude, because phytoplankton attributes other than size, such as shape or chemical properties, are also considered to influence food selection (DeMott 1989).

The community structure of mesozooplankton and metazoan microplankton used in the grazing experiments corresponded with that found in the euphotic zone of the study site (A. Uitto unpubl.). Ciliates may have increased the BSCR of the metazoan microplankton size fraction in August, and thus the grazing may be slightly overestimated in the last experiment. Graz- 
ing estimations based on measurements made with naturally occurring zooplankton communities remove some of the uncertainty associated with extrapolation from laboratory experiments, but reveal the grazing at only one depth and time of day. Primary production, the community structure and biomass of auto- and heterotrophs, and the grazing efficiency of zooplankton may vary even at different depths in the euphotic zone (Lambert \& Taylor 1985). An experimental frequency of twice a month may also be too low to recover all temporal changes potentially connected to metazooplankton grazing dynamics. However, this study gives the first estimate based on real measurement of mesozooplankton and metazoan microplankton in the study area, and the estimated daily grazing efficiencies fit well with earlier measurements conducted in the southern Baitic and other sea areas.

Acknowledgements. This study was carried out under project PELAG at the Tvärminne Zoological Station. I thank Drs Riitta Pajuniemi and Harri Kuosa for the enumeration of microzooplankton and phytoplankton samples and Dr Risto Lignell for the primary production data. Drs Anna-Stiina Heiskanen, Kai Kivi, H. Kuosa, and Risto Lignell made valuable comments on the manuscript. The English language was revised by Drs Susan Cowell and Laurie Friday. Financial support from the Walter and Andrée de Nottbeck Foundation and the Academy of Finland is also acknowledged.

\section{LITERATURE CITED}

Arndt H, Schröder C, Schnese W (1990) Rotifers of the genus Synchaeta - an important component of the zooplankton in the coastal waters of the southern Baltic. Limnologica 21:233-235

Bautista B, Harris RP (1992) Copepod gut contents, ingestion rates and grazing impact on phytoplankton in relation to size structure of zooplankton and phytoplankton during a spring bloom. Mar Ecol Prog Ser 82:41-50

Bergreen U, Hansen B, Kiørboe T (1988) Food size spectra, ingestion and growth of the copepod Acartia tonsa during development: implications for determination of copepod production. Mar Biol 99:341-352

Bogdan KG, Gilbert JJ (1982) Seasonal pattern of feeding by natural populations of Keratella, Polyartha, and Bosmina: clearance rates, selectivities, and contributions to community grazing. Limnol Oceanogr 27:918-934

Conover RJ, Mayzaud P (1.984) Utilization of phytoplankton by zooplankton during the spring bloom in a Nova Scotia inlet. Can J Fish Aquat Sci 41:232-244

Cyr H, Pace ML (1993) Allometric theory: extrapolations from individual to communities. Ecology 74:1234-1245

Dam HG, Peterson WT (1988) The elfect of temperature on the gut clearance rate constant of planktonic copepods J Exp Mar Biol Ecol 123:1-14

Dam HG. Peterson WT (1991) In situ feeding behaviour of the copepod Temora longicornis: effects of seasonal changes in chlorophyll size fractions and female size. Mar Ecol Prog Ser 71:113-123

Daro $\mathrm{MH}$ (1978) A simplafied ${ }^{14} \mathrm{C}$ method for grazing measurements on natural planktonic populations. Helgoländer Wiss Meeresunters 31:241-248
DeMott WR (1989) Optimal foraging theory as a predictor of chemically mediated food selection by suspension-foeding copepods. Limnol Oceanogr 34:140-154

DeMott WR, Kerfoot WC. (1982) Competition among cladocerans: nature of the interaction between Bosmina and Daphnia. Ecology 63:1949-1966

Durbin AG, Durbin EG, Wladarczyk E (1990) Diel feeding behaviour in the marine copepod Acartia tonsa in relation to food availability. Mar Ecol Prog Ser 68:23-45

Durbin EG, Durbin AG (1992) Effects of temperature and food abundance on grazing and short-term weight change in the marine copepod Acartia hudsonica. Limnol Oceanogr $37: 361-378$

Edler L (1979) Recommendations on methods for marine biological studies in the Baltic Sea. Phytoplankton and chlorophyll. Baltic Marine Biologists Publ 5:1-36

Forsskảhl M, Sundberg A (1981) Abundance, biomass, species composition of phyto- and zooplankton and their interrelations at the entrance of the Gulf of Finland. Meri 9:43-55

Gulati R (1985) Zooplankton grazing methods using radioactive tracers: technical problems. Hydrobiol Bull 19:61-69

Gulati R, Doornekamp A (1991) The spring-time abundance and feeding of Eurytemora affinis (Poppe) in VolkerakZoommeer, a newly-created freshwater lake system in the Rhine delta (The Netherlands). Hydrobiol Bull 25:51-60

Haney JF (1971) An in situ method for measurement of zooplankton grazing rates. Limnol Oceanogr 16:971-977

Hessen DO, Nilssen JP, Eriksen TO (1986) Food size spectra and species replacement within herbivorous zooplankton. Int Rev Ges Hydrobiol 71:1-10

Huntley M. Brooks ER (1982) Effects of age and food availability on diel vertical migratıon of Calanus pacificus. Mar Biol 71:23-31

Huttunen M, Kuparinen J (1986) Species succession and productivity of ultraphytoplankton in the pelagic off Tvärminne, SW coast of Finland. Ophelia Suppl 4:73-83

Kankaala P (1983) Resting eggs, seasonal dynamics, and production of Bosmina longispina maritima (P. E. Müller) (Cladocera) in the northern Baltic proper. J Plankton Res 5:53-69

Kankaala P, Wulff F (1981) Experimental studies on temperature-dependent embryonic and postembryonic rates of Bosmina longispina maritima (Cladocera) in the Baltic. Oikos 36:137-146

Kirboe T, Møhlenberg F, Riisgård HU (1985) In situ feeding rates of planktonic copepods: a comparison of four methods. J Exp Mar Biol Ecol 88:67-81

Kivi K (1986) Annual succession of pelagic protozoans and rotifers in the Tvärminne Storfjärden. SW coast of Finland. Ophelia Suppl 4:101-110

Lambert W, Taylor B (1985) Zooplankton grazing in a eutrophic lake: impacts of diel vertical migration. Ecology $66: 68-82$

Lasker R (1966) Feeding, growth, respiration, and carbon utilization of an euphasiid crustacean. J Fish Res Bd Can 23: $1291-1317$

Lignell R, Heiskanen AS, Kuosa H, Gundersen K, KuuppoLeinikkı P, Pajuniemi R, Uitto A (1993) Fate of a phytoplankton spring bloom: sedimentation and carbon flow in the planktonic food web in the northern Baltic. Mar Ecol Prog Ser 94:239-252

Lindholm I (1981) On the ecology of Mesodinium rubrum (Lohmann) (Ciliata) in a stagnant brackish basin on Aland, SW Finland. Kieler Meeresforsch, Sonderh 5:117-123

Markager S, Hansen B, Sondergaard M (1994) Pelagic carbon metabolısm in a eutrophic lake during a clear-water phase. J Plankton Res 16:1247-1267 
Mazumder A. McQueen DJ, Taylor WD, Lean DRS, Dickman MD (1990) Micro- and mesozooplankton grazing on natural pico- and nanoplankton in contrasting plankton communities produced by planktivore manipulation and fertilisation. Arch Hydrobiol 118:257-282

Moloney CL, Field JG (1989) General allometric equations for rates of nutrient uptake, ingestion, and respiration in plankton organisms. Limnol Oceanogr 34: $1290-1299$

Morales CE, Harris RP, Head RN, Tranter PRG (1993) Copepod grazing in the oceanic Northeast Atlantic during 6 week drifting station: the contribution of size classes and vertical migrants. J Plankton Res 15:185-211

Mullin MM (1969) Production of zooplankton in the ocean: the present status and problems. Oceanogr Mar Biol A Rev $7: 293-310$

Nicolajsen H, Møhlenberg F, Kiorboe T (1983) Algal grazing by the planktonic copepods Centropages hamatus and Pseudocalanus sp. diurnal and seasonal variation during the spring phytoplankton bloom in the Øresund. Ophelia 22:15-31

Niemi, $\AA$ (1973) Ecology of phytoplankton in the Tvärminne area, SW coast of Finland. I. Dynamics of hydrography, nutrients, chlorophyll $a$ and phytoplankton. Acta Bot Fenn $100: 1-68$

Niemi M, Kuparinen J, Uusi-Rauva A. Korhonen K (1983) Preparation of ${ }^{14} \mathrm{C}$-labelled algal samples for liquid scintillation counting. Hydrobiologia 106:149-156

Paffenhöfer GA (1971) Grazing and ingestion of nauplii, copepodids and adults of marine planktonic copepod Calanus helgolandicus. Mar Biol 11:286-298

Peters RH (1984) Methods for the study of feeding, grazing and assimilation by zooplankton. In: Downing JA, Rigler $\mathrm{FH}$ (eds) A manual for the assessment of secondary productivity in fresh waters. IBP Handbook 17 Blackwell, Oxford, $\mathrm{p} 337-413$

Peters RH, Downing JA (1984) Empirical analysis of zooplankton filtering and feeding rates. Limnol Oceanogr 29 : $763-789$

Riemann B, Sørensen HM, Bjørnsen PK, Horsted SJ, Jensen LM, Nielsen TG, Sondergaard M. (1990) Carbon budgets

This article was submitted to the editor of the microbial food web in estuarine enclosures. Mar Ecol Prog Ser 65:159-170

Tackx MLM, Bakker C, van Rijswijk P (1990) Zooplankton grazing pressure in the Osterschelde (The Netherlands). Neth J Sea Res 25:405-415

Tiselius P (1988) Effects of diurnal feeding rhythrns, species composition and vertical migration on the grazing impact of calanoid copepods in the Skagerrak and Kattegat. Ophelia 28:215-230

Tiselius P (1.989) Contribution of aloricate ciliates to the diet of Acartia clausi and Centropages hamatus in coastal waters. Mar Ecol Prog Ser 56:49-56

Turner JT, Tester PA (1989) Zooplankton feeding ecology: nonselective grazing by the copepods Acartia tonsa Dana, Centropages velificatus De Oliveira, and Eucalanus pilcatus Giesbrecht in the plume of the Mississippi River. J Exp Mar Biol Ecol 126:21-43

Utermöhl H (1958) Zur Vervollkommnung der quantitativen Phytoplankton-Methodik. Mitt Int Verein Theor Angew Limnol 29:117-126

Uye S, Huang C, Onbe T (1990) Ontogenetic diel vertical migration of the copepod Calanus sinicus in the Inland Sea of Japan. Mar Biol 104:389-396

Vadstein O, Harkjerr O, Jensen A (1989) Cycling of organic carbon in the photic zone of a eutrophic lake with special reference to the heterotrophic bacteria. Limnol Oceanogr $34: 840-855$

Viitasalo $M$ (1994) Seasonal succession and long-term changes of mesozooplankton in the northern Baltic Sea Finn Mar Res 263:3-39

Vuorinen I Ranta E (1987) Dynamics of marine mesozooplankton at Seili, northern Baltic Sea, in 1967-1975 Ophelia 28:31-48

Webster KE, Peters RH (1978) Some size-dependent inhibitions of larger cladoceran filterers in filamentous suspensions. Limnol Oceanogr 23:1238-1245

White JR, Roman MR (1992) Seasonal study of grazing by metazoan zooplankton in the mesohaline Chesapeake Bay. Mar Ecol Prog Ser 86:251-261

Zánkai NP (1991) Feeding of nauplius stages of Eudiaptomus gracilis on mixed plastic beads. J Plankton Res 13:437-453

Manuscript first received: November 8,1994

Revised version accepted: September 7, 1995 